\title{
LXV. On matting made from the Typha latifolia, or greater cat's-tail
}

\author{
Mr. William Salisbury
}

To cite this article: Mr. William Salisbury (1822) LXV. On matting made from the Typha latifolia, or greater cat's-tail, Philosophical Magazine Series 1, 59:288, 288-290, DOI: 10.1080/14786442208652742

To link to this article: http://dx.doi.org/10.1080/14786442208652742

里 Published online: 29 Jul 2009.

Submit your article to this journal $₫$

Џ Article views: 3

Q View related articles $\asymp$ 
sicians equally worthy of credit, may be owing in a great measure to different manners of operating; some in fact contenting themselves with isolating the patient, and placing him in communication with the conductor of the machine, while others have regularly introduced the fluid into the suffering part by means of discharges more or less violent. But without saying more on this point at present, let us attend to the following fact, which we extract from one of the scientific journals published in America.

M. Samuel Leffers, of Carteret County, in Nurth Carolina, had been seized with a paralytic affection which fixed itself on the face, and principally on the eyes. As he was walking in his chamber, a flash of lightning struck him down senseless; he came to himself at the end of twenty minutes, but he did not recover perfectly the use of his legs for the rest of the day and night. The next day he found himself quite recovered, and he sat down to write to one of his friends an account of what had happened to him; his letter was very long, and he wrote it without the help of glasses. Since then his paralysis las never returned. M. Leffers thinks that the same shock which restored his sight, has on the other hand injured the delicacy of his hearing.

The article from which we have extracted this case, is from the pen of M. Olmsted, professor of chemistry in the college of North Carolina.

LXV. On Malling made from the Typha latifolia, or Greater Cat's-Tail. By Mr. William Salisbury*.

$\mathbf{T}$ HE praiseworthy and successful endeavours of Mr. Salisbury, to open a new source of industry, peculiarly within the reach of the labouring poor, and of parochial workhouses, have received the approbation of the Society; both on their own account, and in the hope, that, by being recorded in their volume, they may excite others to similar exertions. A material hitherto unemployed, the spontaneous produce of pools and irreclaimable swamps in every part of the kinglom, peculiarly fitted to serve as the basis of domestic manufacture in the cottages of the poor, and the produce of which, whether sold or employed by the makers, will contribute essentially to the increase of their comforts, is not to be lightly passed over. One of the most serious privations to which cottagers in the agricultural districts are exposed, is that of cold during winter, arising in part from the inadequate shelter afforded by the hovels in which they live, and from the

* From the Transactions of the Society for the Encouragement of Arts, Manufactures, and Commerce, p. riii. and p. 52. The Society's Ceres Medal was roted to Mr. Sulisbury for this communication. 
want of bedding. Their own pecuniary resources are but too often insufficient to supply the more imperious demands for food and clothing ; so that, in ordinary circumstances, their sufferings from cold, during the hours intended by nature for repose and restoration, are excessively severe; as those well know, who have seen, with satisfaction not unmingled with sorrow, the joy which the donation of a single blanket invariably produces. If those who have the opportunity, would instruct and encourage the industrious poor in the manufacture of matting from the Typha, they would thus be enabled to supply themselves with an article, which, when employed as a cover to their damp floors, as curtains to their couches, and as an auxiliary to their scanty stock of bedding, would most materially contribute both to their comfort and to their health.

The material of which matting, and the rush-bottoms (as they are called) of chairs, are usually made, is the Scirpus lacustris, known in some parts of England by the name bull-rush, and in Durham and Northumberland by that of pelecive. It grows naturally in deep slow streams, and is particularly abundant in the neighbourhood of Newport Pagnel in Buckinghamshire.

The demand for this article, however, in the Newport Pagnol manufactories is considerably greater than that district can supply ; and, in consequence, large importations of the Scirpus are made from Holland. Hence, in time of war, the article is often scarce, and at an exorbitant price.

Prior to the winter of $1817, \mathrm{Mr}$. Salisbury, induced by a laudable desire of opening new sources of industry to the unemployed poor, attempted, in varions ways, to apply the leaves of the Typha latifolia (Aag, or greater cat's-tail) to the same purposes as the Scirpus. For this purpose he was allowed, by the overseers of the parish of St. George, Hanover-syunare, to employ some of their paupers in collecting about $2 \frac{1}{2}$ tons of the $7 y$ pha from the marshy grounds about Little Chelsea and Claphan; and afterwards in manufacturing a part of it into mats, baskets, hassocks, chair-bottoms, \&c.

Samples of these various articles were laid before the Society in December 1817; and it appeared, that with equal skill in manipulation, equally neat work might be produced from the Scirpus and from the Typha. It being, however, a matter of considerable importance to ascertain the relative durability of the two articles under similar circumstances of ordinary wear, the following experiment was made :-A piece of the best Dutch matting, at $2 s .6 d$. a yard, and a similar one of Mr. Salisbury's manufacture, were laid down side by side in the Society's premises on the 13th of December 1817. Their relative situations were occasionally changed, in order to equalize, as nearly as posVol. 59. No.289. April 1822.

O o sible, 
sible, the wear to which they are exposed; and on 27th March 1821 they were taken up and examined by the Committee of Manufactures. On minute inspection, they appeared to be about half worn out, and there was no very perceptible difference in the condition of each.

With regard to the relative expense of procuring and preparing the two articles for manufacture, the Society possess no very certain data ; as the use of the Typha was at first set on foot chiefly in order to employ those parish poor who would otherwise have been idle. Two guineas were paid by $\mathrm{Mr}$. S. for liberty to cut as much of the Typha as he pleased from about ten acres of swampy land near Harnmersmith. The matting has been sold at from $9 d$. to $15 d$. per yard, and between 1000 and 1500 yards have been disposed of during the last three years.

The Typha abounds in all marsh ditches and uncultivated swampy ground in every part of the kingdom ; whereas the Scir$p u s$ is found in quantity sufficient for manufacture only in certain districts : hence the former must be much more accessible and cheaper than even the Scirpus of home growth; and the Society indulge the hope, that, by giving this notice a place in their annual volume, the knowledge and the use of so abundant and cheap a material may be extended throughout the kingdom, and may form a means of domestic employment to the younger members of poor families.

LXVI. On a luminous Appearance seen on the dark Part of the Moon in May 1821. Communicated in a Letter to the Rev. Dr. Pearson, from the Rev. M. WaRd*.

Dear Sir,-I have this moment laid aside my telescope from an examination of the moon. The atmosphere was more favourable for the purpose than $I$ have observed it to be for many weeks; and as it so happened, that at about the same age of the last moon, I had carefully examined the part in obscurity to look for a volcano, and had not in any part observed a remarkable appearance, I was greatly surprised to find a paragraph in the public papers, giving a detailed account of a volcano near Aristarchus, seen on the very night I had satisfied myself that there was not even an appearance which could be mistaken for a volcano. I resumed the attempt this evening; and having passed the enlightened part of the moon from the field, and carefully avoided looking at it, to have my eye in the best state to discover any more conspicuously illuminated spot in the unenlightened part, I soon saw Aristarchus very clearly, having very

* From the Memoirs of the Astronomical Society of London. 